\title{
Heythrop, Copleston, and the Jesuit Contribution to Philosophy ${ }^{1}$ JOHN HALDANE
}

\begin{abstract}
There has been public outcry from philosophers and others at the prospect of the closure of Heythrop College, University of London; yet the nature and history of Heythrop remain little known. It is apt and timely, therefore, as its likely dissolution approaches, to provide a brief account of its origins and development up to and including the period of its entry into London University under the leadership of the most famous modern historian of philosophy Frederick Copleston. Following on from this the idea of a distinctive Jesuit intellectual tradition, and more specifically of the Jesuit contribution to philosophy is explored.
\end{abstract}

If we once make the transition to metaphysical reflection (and nobody can compel us to do this), the immanent direction of the mind or reason to the One asserts itself. ... Transcendence, in the active sense of transcending, belongs to man as much as does being in the world. And in my opinion metaphysics can be looked on as man's appropriation in reflection of his own orientation to the transcendent Absolute.

Frederick Copleston 'Man, Transcendence and the Absence of God' 2

\footnotetext{
${ }^{1}$ The present essay derives from a lecture given at Senate House London as part of the celebration of Heythrop's quartocentenary. I am grateful to the then Principal, Michael Holman S.J. for the invitation to contribute to that occasion. I received useful suggestions and comments from Kevin Flannery S.J., Joseph Godfrey S.J. and Patrick Riordan S.J.

${ }^{2}$ See Copleston, Philosophers and Philosophies (London: Search Press, 1976) 62.
} 
In 2014 the quartocentenary of Heythrop College was celebrated with a two-day conference in the Senate House of London University and with the publication of a commemorative history. ${ }^{3}$ Within a year, however, Heythrop's Governing body decided that in 2018 the College should 'come to an end' as a constituent member of the University of London. In the absence of any scheme for it to continue otherwise this means that it will then cease to exist simpliciter. ${ }^{4}$ Heythrop is a singular institution, at once the smallest and oldest of the London University colleges, predating the next oldest by over two hundred years, yet the most recent to have been incorporated, entering in 1970-71. It is also unique among British colleges and universities in having been established to teach philosophy and theology, and in confining itself to these. Additionally it is the founding home of the well-known academic periodical The Heythrop Journal established to promote research in these two fields.

In the months following the Governors' decision there was much public discussion including multi-signatory open letters published in the Tablet, the Times, the Times Higher and on websites. The writers included the Chair of the Philosophy Faculty Board at Oxford, a dozen heads of other UK philosophy departments and programmes, the President of the British Philosophical Association, and the Master of Magdalene College Cambridge (the former Archbishop of Canterbury Lord Williams), along with many other philosophers and theologians. The writers all emphasised the distinctness of the contribution made by

\footnotetext{
${ }^{3}$ Michael J. Walsh, Heythrop College 1614-2014: A Commemorative History (London: Heythrop College, 2014).

${ }^{4}$ During 2015 and 2016 the College had extended discussions with two other London universities, St Mary's University, Twickenham, and the University of Roehampton, about the possibility of merging with one or other of these, but it was concluded that no such arrangement was feasible.
} 
Heythrop: 'It would be a tragedy if this unique Jesuit college, with its centuries'-old history, were allowed to go under now, at the very time when it is making a really significant contribution to philosophical and theological research both nationally and internationally'; 5 'Heythrop is not an institution that can be replaced by anything equal or equivalent to it'; 6 and 'The college offers a unique approach to the study of philosophy'.

Notwithstanding its distinctiveness, and the widely reported ongoing public outcry by philosophers, theologians and others at the prospect of its closure ${ }^{8}$, the nature and history of Heythrop remain little known. It is apt and timely, therefore, as its likely dissolution approaches, to provide some account of its origins and development up to and including the period of its entry into London University under the leadership of the most famous modern historian of philosophy Frederick Copleston. ${ }^{9}$ My main aim, however, is to explore what is impressionistically associated with it as an institution (as with other Jesuit universities such

\footnotetext{
${ }^{5}$ A. Ainley et al. 'Philosophers call for Heythrop College to be saved', Tablet, 25 July 2015

${ }^{6}$ S. Coakley et al, 'Threat to theology' The Times 18 August 2015.

${ }^{7}$ A. Assiter et al. 'Don't Shut Down Heythrop College' Times Higher, 6 August 2015.

${ }^{8}$ See further multi-signatory letters The Tablet 22 July 2016.

${ }^{9}$ In the following section I am indebted to a large number of sources including M. Cretineau Joly, The Poor Gentlemen of Liege being the History of the Jesuits in England and Ireland for the last Sixty Years, trans. R. J. McGhee (London: Shaw \& Co., 1863), Ethelred L.
} Taunton, The History of the Jesuits in England 1580-1773 (London: Methuen, 1901), Henry Chadwick S.J. St Omers to Stonyhurst (London: Burns and Oates, 1962), Francis Edwards, S.J., The Jesuits in England (Tunbridge Wells: Burns and Oates, 1985), Bernard Bassett S.J., The English Jesuits from Campion to Martindale (Leominster: Gracewing, 2004), Michael Walsh, Heythrop College, op. cit., and Frederick C. Copleston, Memoirs of a Philosopher (Kansas City, MO.: Sheed \& Ward 1993). 
as Georgetown in the US and the Gregorian in Rome) or otherwise vaguely alluded to, namely the idea of a distinctive Jesuit intellectual tradition, and more specifically of the Jesuit contribution to philosophy, also to indicate ways in which Copleston himself represented that contribution.

II

Heythrop is the direct descendent of a Jesuit house of scholastic studies established in 1614 in the former residence of the Knights of the Order of St John in Louvain. Following the Reformation, Catholic colleges had been prohibited in Britain and Ireland leading to a flow of teachers to the Continent and the establishment there of English, Scots and Irish colleges. Some of these were associated with secular clergy, others with religious orders and societies such as 'the Jesuits' Societas Jesu). ${ }^{10}$ In 1593 Robert Persons S.J., (later and now generally spelt 'Parsons') a sometime fellow and tutor of Balliol College Oxford, who had previously been involved in founding English colleges for the training of priests in Valladolid (1589) and in Seville (1592), recognized the need for the education of lay students and established for that purpose the Jesuit English College of Saint-Omer in northern France. ${ }^{11}$ There was, however, a growing number of Englishmen seeking to become Jesuits, and with the agreement of the Society's Superior General in Rome, Claudio Acquaviva, Parsons bought 'St John's' in Louvain to establish a house of study for these recruits. It began in 1607 but Jesuit regulations required a separation of 'novices' (who might not proceed to the priesthood), and 'scholastics' (advancing towards ordination) whose education was lengthy

${ }^{10}$ The word 'Jesuit' like 'Gothic' was originally used as a pejorative and only later came to be adopted as a simple descriptive.

${ }^{11}$ See Michael L. Carrafielo, Robert Parsons and English Catholicism 1580-1610 (London: Associated University Presses, 1998). 
and involved higher studies in philosophy and theology. In 1614 the novices moved to a new building and the following year relocated to Liege, while the former house of the Knights of St John became the English Jesuit College. British and Irish Catholic 'exiles' were generally dependent upon lay benefactors. Parsons had purchased St John's House with a donation bequeathed for an English noviceship by Doña Luisa de Carvajal y Mendoza and the separated scholasticate was given an endowment by Thomas Sackville whose late father was the Earl of Dorset, Lord High Treasure of England and Chancellor of Oxford University. A later anonymous donor was almost certainly Sir George Talbot, subsequently ninth Earl of Shrewsbury.

In 1624 the scholasticate followed the novitiate in relocating to Liege which was then an independent city under the governance of a brother of Duke Maximilian of Bavaria, himself a friend of Talbot's, and the Duke provided the college with an annual grant. In Liege, as at Louvain, scholastics were taught philosophy which was a prescribed element in the Jesuit curriculum as set out in the official version of the Ratio $\underline{\text { Studiorum }}^{12}$ promulgated from Rome by Acquaviva in 1599. In this scheme the standard philosophical author was Aristotle, and the favoured theologian Aquinas, in each case taught partly through commentaries, several of which were Jesuit authored . This remained the plan of studies through to the suppression of the Society by Pope Clement XIV in 1773. Subsequent to that the educational identity changed from a college for Jesuit scholastics to a school then titled Liege Academy, for seminarians and lay pupils.

In 1794 Liege came under French attack, and with France also being at war with England the Jesuits and students were at risk. By then, however, the situation for Catholics in England was improving. Clement's immediate predecessor (Clement XIII) had recognized

${ }^{12}$ Ratio atque Institutio Studiorum Societas Jesu - 'Method and system of the studies of the Society of Jesus'. 
the Hanovarian dynasty as legitimate rulers of the United Kingdom. By reciprocation the penal laws against Catholics were less rigorously enforced leading to the first relief Act of 1782 which allowed the establishment of Catholic schools. The decision was made, therefore, to return home and in July 1794 the community left for England. A Catholic recusant Thomas Weld of Lulworth who had been educated at the College of Saint Omer, gave them Stonyhurst a large house in the Ribble Valley in Lancashire. In 1814 Pius VII lifted the suppression and restored the Society, and in the following decades the Stonyhurst settlement grew. It included a lay boys school and a Jesuit scholasticate, St Mary's Hall, the latter continuing the work of the original Louvain foundation. For its first two decades the University of London served only as an examining body for students of University College and King's and a granter of external degrees to students studying at other approved institutions. In 1840 Stonyhurst acquired this status.

Thereafter philosophy and theology were divided: the former continuing to be provided at St Mary's; the latter being taught in a new 'theologate' foundation, St Beuno's College in north Wales. This separation was at odds, however, with the Aristotelian-Christian synthesis advanced by Aquinas and which was the ideal for the early Jesuits. The then Superior General in Rome, Wlodimir Ledóchowski S.J., encouraged the English Jesuits to rectify the division by developing a college in which the subjects would be reintegrated and to locate such a Collegium Maximum close to a major British university so that scholastics and their teachers might avail themselves of a larger academic environment, to which they might also hope to contribute.

In 1875 the Jesuits had built St Aloysius church on Woodstock Road in Oxford (adjacent to which Somerville Hall (later 'College') was founded in 1894), and in 1896 Richard Clarke, fellow of St John's and later of Trinity who had converted to Catholicism and become a Jesuit, set up a private hall for the teaching of Catholic students in the 
University. By the end of World War I this latter had grown in scale and ambition, and in 1918 it was granted the status of Permanent Private Hall. At that point it was renamed by the Jesuits 'Campion Hall' in honour of Edmund Campion the Elizabethan Fellow of St John's, who later became a Jesuit and was executed at Tyburn in 1581. The existing presence in Oxford, and the fact that many Jesuits were themselves graduates of the University gave reason to locate the new Collegium Maximum nearby, and in 1923 a large but somewhat ruinous country house Heythrop Hall was acquired for the purpose. Its Baroque design, a tradition of which the Jesuits had been patrons since the seventeenth century, and the fact that it had been built for Charles Talbot a descendent of the donor to Louvain/Liege added to the suitability of the choice. Restored, refurbished and stocked with the extensive collections of philosophical and theological books from Stonyhurst and St Bueno's it began its work in 1926. ${ }^{13}$

Students in philosophy and theology were able to receive degrees of the Jesuit Gregorian University in Rome, but the idea was conceived that it might itself become a degree awarding institution and thus it established a Pontifical Athenaeum admitting also non-Jesuit religious and lay students. The scheme, however, was neither economically nor academically satisfactory and in 1967/8 the idea began to be discussed of transferring to the campus of a secular university. ${ }^{14}$ Five possibilities were considered: Bristol, Nottingham, Oxford, London and Manchester, leading to a choice between the last two. Manchester made a favourable offer but London was judged to be more apt, in part because being a federal institution Heythrop could preserve its identity as a college within it. Thus in 1969 Heythrop

\footnotetext{
${ }^{13}$ Now considerably enlarged, the Heythrop College collection is widely acknowledged to be one of the finest theological and philosophical libraries in the UK.

${ }^{14}$ For accounts of this phase see the extensive discussion in Walsh, op.cit., and the privileged perspective provided in Frederick C. Copleston, Memoirs of a Philosopher op. cit.
} 
applied to become part of the University, undertaking to move to the capital and to suspend the Athenauem. The application was accepted and in 1971 the Privy Council granted permission for it to become a constituent school of the University. ${ }^{15}$

Prior to the London initiative heads of the College were titled 'rector' but in keeping with the style of the host institution the head position was retitled 'Principal' and it was as such that Frederick Copleston took up office in 1970 the same year in which he became a Fellow of the British Academy. It was his first significant administrative responsibility and he found the task of aligning the interests and expectations of the College and the University difficult and burdensome. By his own account, however, he was greatly helped by the patience, advice and support of the first the chairman of the board of governors David Hamlyn, then professor and chair of the department of philosophy at Birkbeck College, who had just succeeded Gilbert Ryle as editor of Mind. Hamlyn expressed admiration for Copleston's work in effecting the transition of the College from a religious house of higher studies, specifically a Jesuit scholasticate, to its identity as a constituent school of the University. ${ }^{16}$ The regard was reciprocal for in his Memoirs (the production of which derived in part from a suggestion by Hamlyn that he should write an account of his life) Copleston expresses his gratitude to Hamlyn 'for his interest in the fledgling College, and for the way in which, as chairman of the governing body, he helped to guide Heythrop through its first

\footnotetext{
${ }^{15}$ For its first near quarter century the College was housed in central London behind the neoPalladian facades of two conjoined buildings in Cavendish Square. In 1993 it moved to Kensington Square, a more spacious and quieter location allowing it to increase student numbers. Both sets of buildings had previously been occupied by Catholic teacher training colleges run by women religious orders: the Sisters of the Society of the Holy Child Jesus, and the Religious of the Assumption.

${ }^{16}$ In personal conversations with the present writer.
} 
years' ${ }^{17}$ The two men shared a deep admiration for Schopenhauer, unusual then among British philosophers, each publishing books on him. ${ }^{18}$ Hamlyn later contributed to a Festschrift celebrating Copleston's work as a historian of philosophy ${ }^{19}$ while Copleston wrote a 'Critical Notice' of Hamlyn's Being a Philosopher, a history of the practice of philosophy. ${ }^{20}$ They worked together to ensure a secure relationship between College and University but shared between themselves serious concerns about the long-term feasibility of sustaining a small and somewhat unworldly community engaged exclusively with philosophy and theology within the context of a large and largely secular federal university driven by a funding regime that favoured big multi-subject institutions. ${ }^{21}$ From that perspective they

${ }^{17}$ Copleston, op. cit., 165.

${ }^{18}$ F. C. Copleston, Arthur Schopenhauer: Philosopher of Pessimism (London: Burns, Oates \& Washbourne, 1947), and D.W. Hamlyn, Schopenhauer (London: Routledge, 1980).

${ }^{19}$ D. W. Hamlyn, ‘Aristotle's God' in Gerard J. Hughes ed. The Philosophical Assessment of Theology: Essays in Honour of F. C. Copleston (Washington, D.C.: Georgetown University Press, 1987).

${ }^{20}$ Copleston, 'Critical Notice of Being a Philosopher' Philosophical Quarterly 43 (1993), 505-12. This was written at the request of the present author to whom Copleston wrote 'It seems to me that I might very well wish to avail myself of your suggestion about combining commentary on Professor Hamlyn's book with general reflections on the history of philosophy', letter dated 19 $9^{\text {th }}$ June 1992. Copleston died in February 1994 and this review was one of his last pieces of academic writing.

${ }^{21}$ Walsh, Heythrop College, 132 quotes from a letter sent privately by Hamlyn to Copleston in 1974 expressing his concerns about the financial plan of the College: 'It is clear to me that the College was set up in London under serious misapprehensions about the financial consequences and whatever happens those mistakes must be made good. If they are not I 
might well have been surprised less by the announcement of its closure than by the fact that it survived as part of London University for almost half-a-century.

III

What might it mean to speak of Heythrop's distinctive tradition in teaching and scholarship in philosophy? There is a common impression that the Jesuits have been associated with a particular philosophical tradition, perhaps in the way that Franciscans were associated with Augustinianism and Dominicans with Thomism, but this impression remains indistinct.

The phrase 'the Jesuit contribution to philosophy' calls for a substantial treatment and one might have supposed that such a study had already been produced, but no such work has yet been written. Even Copleston who would have been well qualified to do so never took on that task, perhaps reflecting his unpartisan temperament, though he does discuss aspects of the Jesuit contribution and influence in the third and fourth volumes of his monumental History of Philosophy. There is certainly a role for such a comprehensive study, and even an extended outline for it could serve as an informative encyclopedia entry, but what is called for beyond a selection of notable contributions is a thesis or a unifying idea.

Before I proceed to that, however, let me note a second difficulty, for aside from the issue of comprehensiveness there is a question of whether there has been a singular and determinate input, be it over an extended period. Anyone familiar with the discipline of intellectual history, the plurality of Jesuit thought and the diversity of intellectual cultures within which Jesuits have worked would doubt this is so. Should one then speak instead of 'some Jesuit contributions'? Confining oneself to a few examples would make the task easier,

shall have no recourse to resign [as chair of governors] and I shall do so in a way that makes clear why I am doing so’ (original letter from Boston College Library, manuscripts collection, Copleston papers, box 11, file 1). 
but then the challenge to look for some kind of unity of purpose, method or approach, if not a unitary doctrine, might be too easily side-stepped.

IV

Thinking about Jesuit contributions to philosophy it is natural to point to writings such as the Disputationes Metaphysicae of Francisco Suarez S.J. (1548-1617) a work of great intellectual depth and complexity, regarded in the period following its publication in 1597 as the most important treatise on metaphysics since Aristotle. ${ }^{22}$ Something of its influence can be detected in the thought of the members of the rationalist trinity: Descartes, Spinoza and Leibniz, which is perhaps not so surprising given that they too were interested in the same set of metaphysical issues about substance and attribute, individuation and identity, possibility and necessity, and real causality, though they each came to rather different, and in the case of the rationalists quite revisionary conclusions about them.

Why then is Suarez not better known as a metaphysician? He is more commonly cited as a moral and political philosopher advocating a form of natural law theory. Although he discussed Aquinas's treatment of Law in the Summa Theologiae, his own quasi-voluntaristic position stands at some distance from Thomas, but it suited the emphasis on divine sovereignty in Calvin, and Suarez's additional view that the law that regulates behavior between nations is customary, rather than derivable a priori, was also well-received by those who sought to oppose what they regarded as the tyranny of Catholic secular power.

These notions had a marked influence on reformed jurists such as Grotius and Pufendorf and one may regard Suarez as the father of normative International Relations

\footnotetext{
${ }^{22}$ For discussions of aspects of Suarez's work and a bibliography of his writings including English translations see B. Hil, and H. Lagerlund, eds. The Philosophy of Francisco Suarez (Oxford: Oxford University Press, 2012).
} 
theory. As $I R$ developed out of law and political science into distinct university departments it sought to establish its depth by identifying founding fathers in earlier centuries. Suarez well serves that role since besides being a modern jurist he was a bridge to Aristotelian and Stoic thought, and a metaphysician besides. The History and Nature of International Relations published in the 1920s in the Georgetown Foreign Service Series has a short Appendix 'Grotius, Suarez and De Victoria' but the order of honour is clear. Citing the $19^{\text {th }}$ century historian Henry Hallam describing Suarez as 'by far the greatest man in the order of moral philosophy, whom the order of Loyola produced in this age, or perhaps any other' the author urges that 'Suarez should be universally recognised as one of the truly great founders of international law, second perhaps only to the great Grotius, if indeed to him' adding: 'In fact, there is little or nothing new in Grotius's general treatment of his subject; his system is fundamentally identical with the ideas outlined by Suarez.' 23

The acknowledgement of Suarez as a moral and social philosopher of importance and influence is appropriate but it leaves out the metaphysics. Yet much of his work in the field of speculative philosophy is of enduring value and engages issues not adequately resolved by his scholastic predecessors and which are again prominent in contemporary metaphysics. This a point to which I shall return. His eclipse might be due to political factors. He was called upon to engage in religious polemics as in the work of 1613 commissioned by Paul V: Defensio catholicae fidei contra anglicanae sectae errors (Defense of the Universal Catholic Faith Against the Errors of the Anglican Sect) which had more to do with the interests of sovereigns and Popes than the cause of religion. Subsequent history also turned against his country Spain, thereby darkening his reputation in the shadow of what Julián Juderías termed the black legend, 'La Leyenda Negra', later characterised by Edwards Peters as

${ }^{23}$ E. A. Walsh, ed. History and Nature of International Relations (New York: MacMillan, 1992) 296-7. 
An image of Spain circulated through late sixteenth-century Europe, borne by means of political and religious propaganda that blackened the characters of Spaniards and their ruler to such an extent that Spain became the symbol of all forces of repression, brutality, religious and political intolerance, and intellectual and artistic backwardness for the next four centuries. ${ }^{24}$

Indeed the political, cultural and economic rise of northern Europe over the Mediterranean powers may be a factor in the minimizing of Catholic, and specifically Jesuit thought in the period from the early seventeenth century onwards. Returning to the case of Suarez as a jurisprudent, James Lorimer, holder of the Regius Chair of Public Law and the Law of Nature and Nations at Edinburgh University (1862-90) writes in his Institutes of the Law of Nations of

... the extreme injustice of the manner of which down to our own time, it has been customary to speak of the scholastic jurists. ... The fact is, that ever since the Reformation the prejudices of Protestants against Roman Catholics have been so vehement as to deprive them of the power of forming a dispassionate opinion of their works, even if they had been acquainted with them, which they rarely were. ${ }^{25}$

${ }^{24}$ E. Peters, Inquisition (Berkeley, CA.: University of California Press, 1988) 131.

${ }^{25} \mathrm{~J}$. Lorimer, The Institutes of the Law of Nations: A Treatise of the Jural Relations of Separate Political Communities (Edinburgh: William Blackwood and Sons, 1883) 71. 
Attitudes have modified, but that change came too late, for in the period when philosophy expanded it also turned against metaphysics, and the recent return has been mostly in an ahistorical and largely historically-uninformed mode. Hence, until the growth of history of philosophy as a specialism (which Copleston's work encouraged), Suarez's metaphysical writings, which are his greatest philosophical achievement, have remained neglected. There is also the fact that Descartes, who may have been directly acquainted with the Disputations ${ }^{26}$ made fundamental innovations in the philosophy of substance, reducing it to two modes: extension and consciousness, which then seemed to make the earlier scholastic views, of which Suarez's Disputations are a complex synthesis, seem not only superseded but entirely misconceived.

A further important factor in the perception of Jesuit philosophy of the early modern period, and a cause of its own orientation towards moral philosophy and subsequent criticism and ridicule, is the involvement of Jesuits in the sixteenth and seventeenth centuries' debates around free will and grace, and in the related Jansenist controversy.

The Council of Trent (1545-63), convened in response to the Reformation movements, gave attention to what it deemed Protestant heresies and as well as condemning them sought to formulate or clarify Catholic doctrine on the issues in question. The sixth session (1547) promulgated a decree on justification (de Justificatione) the process by which the sinner is made righteous. In essence the teaching was that while God is the sole agent of justification the justification involves the free cooperation of the patient with the work of grace. This then asserts the necessity of grace and of free will but there are obvious issues

\footnotetext{
${ }^{26}$ In his reply to the 'Fourth set of Objections', those of Antoine Arnauld, who was a recurrent critic of the Jesuits (see below), Descartes refers to Suarez as 'the first writer who came into my hands' but what he says suggests that he had little knowledge of the details of Suarez's views.
} 
about the compatibility of these and about their relative roles. The Jesuits, who came to prominence at the Council laid emph,asis on free will; and in the decades following it, Luis de Molina S.J. (1535-1600) became the most prominent advocate of a strong libertarian position in opposition to more Augustinian writers who emphasized predestination and the idea of irresistible 'efficacious grace'. His 1588 four volume on treatise on freedom, grace, divine foreknowledge and predestination (De liberi arbitrii cum gratiae donis, divina praescientia, praedestinatione et reprobatione) became and remains one of the most important, and debated, philosophical and theological contributions to these issues. Trent and Molina had the likes of Luther and Calvin in their sights but there was resistance from within Catholicism among those who were concerned that the role of grace and of God's agency might be diminished. There was opposition from Dominican Thomists, but also and more significantly for the subsequent reputation of the Jesuits from followers of the Dutch theologian Cornelius Jansen. The latter whose centre was the Abbey of Port-Royale in Paris, saw themselves as doing no more that reasserting Pauline and Augustinian orthodoxy about original sin, human falleness and the corruption of the moral and intellectual faculties, against Pelagian tendencies, but the Jesuits who coined the term 'Jansenists' viewed them as cryptoCalvinists.

The debates moved further into the area of ethics and specifically the relation of natural law and divine command, and the scope for circumstance, character, and intention to determine moral requirement and evaluation. They became increasingly bitter and the prospect of schism led Popes to intervene, ultimately to condemn the Jansenists; but there was a lasting cost to the reputation of the Jesuits some of whom were also denounced. Important works in the ongoing to and fro were, on the Jesuit side Suarez's De gratia (1619), Antonio Escobar y Mendoza S.J.'s Summula casuum conscientiae (1627) and Liber theologiae moralis (1644), Nicolas Caussin S.J.'s Apologie pour les religieux de la 
Compagnie de Jésus, à la reine régente, and Réponse au libelle intitulé La Théologie morale des Jésuites (both 1644); while on the Jansenist or anti-Jesuitic side stood Jansen's posthumously published Augustinus (1640), Antoine Arnauld's Théologie morale des Jésuites and De la fréquente Communion (both 1643), and, most famously, Pascal's Lettres provinciales (1656-7) published under the pseudonym Louis de Montalte. Pascal was motivated by his attachment to the community of Port-Royal, by a desire to defend Arnauld who had by then come under attack from his fellow theologians of the Sorbonne, and by repugnance at the license to laxity he associated with Jesuit casuistical writings in particular those of Escobar. Pascal was in turn attacked, but his criticism of Jesuitical laxism particularly in letters five and six was taken up and in 1679 in Sanctissimus Dominus Innocent XI (who was himself posthumously accused of Jansenism) condemned many of Escobar's writings as well as casuistical ideas associated with Suarez, terming them 'propositiones laxorum moralisticum'.

I will return briefly to the issue of how one might view the general Jesuit approach in the Jansenist and moral rigorist debates, but so far as cultural perception is concerned there is no doubt that the general verdict, particularly in consequence of Pascal's satirical treatment of casuistry was that Jesuits were clever practitioners of moral sophistry exercised in the interests of accommodating laxity, a verdict preserved in the pejorative use of the term 'Jesuitical'.

\section{V}

Arnauld 's distaste for the Jesuits was partly acquired from his father, also Antoine, who denounced them in a famous speech in 1594, and Antoine junior will not have troubled at the damage done to their reputation as philosophers by his attacks on them as moralists. Descartes' new method displaced their Scholastic-Aristotelian metaphysical tradition but as 
Copleston notes 'at the time when he hoped to get his Principles of Philosophy adopted as a philosophical textbook by the Jesuits, whom he regarded as supreme in the educational sphere, he diminished to some extent his attacks on Scholasticism and renounced the frontal attack which he had threatened' ${ }^{27}$ Descartes had himself been schooled by the Jesuits at La Flèche and is probably the greatest philosopher to have had a Jesuit education. Others include Marin Mersenne (1588-1648) also a product of La Flèche, Giambattista Vico (1668-1744), Denis Diderot (1713-84, educated at Langres), Marquis de Condorcet (1743-94, at Reims), Teilhard de Chardin (1881-1955, at Mongré), Will Durant (1885-1961, at St Peters, Jersey City), Martin Heidegger (1889-1976, at Freiburg), Michel Foucault (1926-84, at SaintStanislaus), and Bernard Lonergan (1904-84, at Loyola, Montreal),

Mersenne, like Descartes, was a convert to the new science, writing in defence of Galileo's cosmology and of his account of the nature of natural substance as composed of particles possessed only of geometrical and dynamic features. He is particularly interesting in this regard, for unlike Descartes who seems to have rejected the scholastic Aristotelianism taught at La Flèche pretty much from the point at which he reflected on it, Mersenne began as a defender of that metaphysics but during the decade 1620-30 converted to the new philosophy of nature, which was effectively physics. It was in the early years of this period (1624) that he published La Vérité des sciences (Truth of the Sciences against the Sceptics) a defence of mathematics and of its role in understanding nature.

This work was known to the Croatian Jesuit mathematician, astronomer and physicist Roger Boscovich S.J. (1711-1787) who was also Jesuit educated, at Collegium Regusinum in Dubrovnik. Beginning in 1745 with De Viribus Vivis he disseminated a somewhat Cartesian view of bodies as exhibiting impenetrability (one atom's occupancy of a location thereby

${ }^{27}$ F. C. Copleston, A History of Philosophy, Volume 4: Descartes to Leibniz (London: Burns \& Oates, 1960) 68. 
excluding another), and proceeded from this exclusionary force conception to advance in Theoria philosophiae naturalis redacta ad unicam legem virium in natura exsitentium (Theory of Natural philosophy derived to the single Law of forces which exist in Nature (1758), a theoretical proof of the nature of body as consisting of discontinuous indivisible points arrayed in a field defined by the forces between them.

It is a reflection of the capacity of Jesuit thinkers to engage with and often adopt the ideas of a given period (a habit some may view as accommodationism, but of which I will give a different account later) that less than a century after Mersenne had taken issue with the Aristotelian metaphysics of his teachers, which was then also being taught at the Gregorian University (formerly the Collegium Romanum), Boscovich was presenting his own version of the new science of bodies at that institution - by then virtually identified with the Jesuits quickly becoming its acknowledged presiding genius and securing a Professorship in 1740. As his ideas became known he was invited to speak across Europe and when visiting London in 1760 he was elected a Fellow of the Royal Society.

One may wonder whether I have strayed from metaphysics to science, or from speculative to natural philosophy; but Boscovich's atomism was a highly theoretical account arrived at not by experiment but by abstract reflection, and just as there are connections with Descartes' account of body as defined by exclusive extension so there are parallels between Boscovich theory of atoms and Leibniz's monadology. Indeed, an advocate of the latter might well have seen Boscovich's theory of unextended point-force centres as a developed application of it to the case of physical bodies. It is reasonable to include Boscovich, therefore, within the broad category of speculative-cum-metaphysical Jesuit thinkers and there is certainly no doubt as to the distinction and influence of his contribution to theoretical 
physics, and to mathematics in which field he considered non-Euclidian geometries half a century before Friedrich Gauss. ${ }^{28}$

It will not have gone unnoticed, however, that this rapid history from one Jesuit, Suarez, to another, Boscovich, has involved a reversal in the fortunes of the kind of metaphysics advanced by the former, a metaphysics broadly continuous with that of medieval thinkers such as Aquinas, Scotus and Ockham, all of whom were taken account of in Suarez's development of theistic Aristotelianism. Certainly there is a continuity inasmuch as Descartes, Mersenne and Boscovich were all taught in Jesuit colleges, but might it not be better to view this as at best incidental and certainly no tribute to Jesuit philosophy per se?

I have given reason to be skeptical about the idea of there being $a$ Jesuit philosophy as such, though it is certainly true that for periods in the history of the order, in the 16th and 17 th centuries and again in the 19th and 20th it has been associated with the defence of Thomism. But to see why one may yet view the history I have sketched as a tribute to a systematic Jesuit engagement with the study of philosophy it is useful to return to where this excurses began, namely Descartes. In his Discourse on Method (1637) he writes of his Jesuit education as follows:

[At La Flèche] I found myself involved in so many doubts and errors, that I was convinced I had advanced no further in all my attempts at learning, than the discovery at every turn of my own ignorance. And yet I was studying in one of the most celebrated schools in Europe, in which I thought there must be

\footnotetext{
${ }^{28}$ For detailed examinations of his ideas see H.V. Gill, S.J. Roger Boscovich: Forerunner of Modern Physical Theories (Dublin: Gill and Son, 1941) and I. Macan \& V. Pozaiac eds. The Philosophy of Science of Roger Boscovich (New York: Fordham University Press, 1988).
} 
learned men, if such were anywhere to be found. I had been taught all that others learned there ...

... I still continued, however, to hold in esteem the studies of the schools. I was aware that the languages taught in them are necessary to the understanding of the writings of the ancients; that the grace of fable stirs the mind; that the memorable deeds of history elevate it; and, if read with discretion, aid in forming the judgment; that the perusal of all excellent books is, as it were, to interview with the noblest men of past ages, who have written them, and even a studied interview, in which are discovered to us only their choicest thoughts; that eloquence has incomparable force and beauty; that poesy has its ravishing graces and delights ... that philosophy affords the means of discoursing with an appearance of truth on all matters, and commands the admiration of the more simple ...

... But I had become aware, even so early as during my college life, that no opinion, however absurd and incredible, can be imagined, which has not been maintained by some one of the philosophers. ${ }^{29}$

These remarks have been taken to amount to a rejection of Jesuit education as represented by what was on offer at La Flèche; but that judgement neglects the fact that Descartes sought to establish his own originality and present himself as independent of conventional teaching, particularly as that was associated with a group under the shadow of northern European anti-Catholic propaganda. A truer picture of his attitude towards his

${ }^{29}$ R. Descartes, Discourse on the Method of Rightly Conducting one's Reason and Seeking Truth in the Sciences, trans. John Veitch (Chicago: Open Court, 1910) 4-5 \& 16. 
education may be revealed in a letter written the following year to a correspondent who had sought advice about his son's education. Descartes replies:

There is no place on earth where philosophy is better taught than at La Flèche ... [and] because philosophy is the key to the other science it is extremely useful to have studied the whole philosophy curriculum, in the manner it is taught in Jesuit institutions, before undertaking to raise one's mind above pedantry in order to make oneself wise in the right kind of philosophy. ${ }^{30}$

The context of a private letter on a matter of personal importance is more likely to draw considered and authentic views than a preface to a work designed to impress by its iconoclasm. We may take this second passage not as a refutation of the first but as providing a lens through which to view it. Descartes could be entirely sincere, and probably quite accurate in saying that a Jesuit education in philosophy was the best to be had, while yet thinking that the philosophy it advocated, viz. scholastic Aristotelianism, had had its day.

The other great philosopher who spent time at La Flèche, though in the neighbourhood and not as a student, and who visited the College to use its excellent library was David Hume. To judge from his comments, however, the only contribution of the Jesuits to his philosophy was to provide grist to his scepticism. In a letter to the philosopher and Presbyterian minister George Campbell who had written in defense of the credibility of miracles as testaments to the Christian religion in reply to Hume's famous attack on it, Hume wrote about the circumstances in which he conceived his skeptical argument:

\footnotetext{
${ }^{30}$ J. Cottingham, R. Striithof, D. Murdoch, \& A. Kenny, The Philosophical Writings of Descartes: Vol. III The Correspondence (Cambridge: Cambridge University Press, 1991) 124.
} 
I was walking in the cloisters of the Jesuits' College of La Flèche a town in which I passed two years of my youth, and engaged in a conversation with a Jesuit of some parts and learning, who was relating to me, and urging some nonsensical miracle performed in their convent, when I was tempted to dispute against him; and as my head was full of the topics of my Treatise of Human Nature which at the time I was composing, this argument immediately occurred to me, and I thought it very much gravelled my companion; but at last he observed to me, that it was impossible for that argument to have any solidity, because it operated equally against the Gospel as the Catholic miracles; - which observation I thought proper to admit as a sufficient answer. I believe you will allow, that the freedom at least of this reasoning makes it somewhat extraordinary to have been the produce of a convent of Jesuits, though perhaps you may think the sophistry of it savours plainly of the place of its birth. ${ }^{31}$

This is not the occasion to engage the philosophical issues but I note just two points: first, Hume's willingness to play upon the familiar prejudices about Catholic superstition and Jesuit sophistry; and second, the fact that he appears never to have troubled to consult the account of the nature of miracles typically advanced in Jesuit presentations which draws from Aquinas's discussion in Summa Theologiae, Ia, q.110, art. 4, and is quite distinct from the conception against which his famous argument is directed.

31 D. Hume, Letter to Rev. George Campbell, 7 June 1762, in J. Greig ed. The Letters of David Hume (Oxford: Oxford University Press, 1932) 361. 
As regards Descartes remark about nothing being so absurd but that some philosopher has advanced it, this is in effect a quotation from Cicero's De Divinatione, II, 119: 'Nothing so absurd can be said that some philosopher had not said it.' (Sed nescio quo modo nihil tam absurde dici potest quod non dicatur ab aliquo philosophorum). Since Descartes would almost certainly have read this with the Jesuits, one wonders whether his remark is an acknowledgement of that introduction, or an ironic and pointed tu quoque. There is also a resonance between his prior ironic remark that "philosophy affords the means of discoursing with an appearance of truth on all matters, and commands the admiration of the more simple' and a disparaging comment by Wittgenstein to Norman Malcolm who reported the former as saying 'What is the use of studying philosophy if all that it does for you is enable you to talk with some plausibility about some abstruse questions of logic, etc.' 32

Mention of Wittgenstein raises the question was he influenced by Jesuit thinkers? I conjecture that he was not, save negatively, because he did not like intellectual priests, thinking 'cleverness' spiritually unbecoming, and his only recorded remarks concerning a Jesuit philosopher are unflattering. Maurice Drury, Wittgenstein's student and friend, records that when he reported hearing (in 1949) that A.J. Ayer and Frederick Copleston were to have a radio discussion on the existence of God Wittgenstein laughed and said 'Oh we musn't miss that - Ayer discussing with a Jesuit, that would be too much to miss'. ${ }^{33}$ In fact the subject of the debate was logical positivism, while the theme of the existence of God had been the topic of a famous debate Copleston had with Russell on the BBC the previous year. Drury may have confused the episodes and the subsequent remark he quotes might refer to Russell not

\footnotetext{
${ }^{32}$ N. Malcolm, Ludwig Wittgenstein (Oxford: Oxford University Press, 1984) 93.

${ }^{33}$ M. O’C Drury, 'Conversations with Wittgenstein' in Rush Rhees ed. Ludwig Wittgenstein: Personal Recollections (Totowa, NJ.: Rowman \& Littlefield, 1981) 172.
} 
Ayer. At any rate, when listening to the broadcast in total silence Wittgenstein's mood became more serious. At the end he observed: 'Ayer [sic.] has something to say but he is incredibly shallow. Fr Copleston contributed nothing at all to the discussion'. There is also a letter from Wittgenstein to Malcolm from 14 June 1949 (the day after the Copleston/Ayer broadcast again suggesting that Drury was thinking of the earlier exchange with Russell) in which he writes 'Yesterday I listened at the radio to part of a discussion between Prof Ayer and a Jesuit about Logical Positivism. I stood 40 minutes of it'. ${ }^{34}$

I will return to Copleston later. Ironically, however, admirers of Wittgenstein have reason to be grateful to two Jesuit philosophers for in one case making his thoughts available, and in the other attempting to make some initial sense of them. The first is Cyril Barrett S.J. who served in the newly founded Department of Philosophy at the University of Warwick from 1965-1992, and edited Wittgenstein's Lectures and Conversations on Aesthetics, Psychology and Religious Belief ${ }^{35}$ the second Garth Hallett S.J. author of one of the first guides to the Philosophical Investigations ${ }^{36}$ who taught at the Gregorian, where he had also studied with Copleston and Bernard Lonergan, before returning to the US to the Jesuit universities of Detroit and then St Louis.

The appearance of the Lectures and Conversations transformed the image of Wittgenstein, revealing him to be exercised by issues in art, psychoanalysis and religion. To that point it was not generally known that he knew of, let alone cared greatly about the thoughts of Cardinal Newman or had reflected upon the therapeutic methods of Sigmund

\footnotetext{
${ }^{34}$ Malcolm, op. cit., 121.

${ }^{35}$ C. Barrett ed. Ludwig Wittgenstein: Lectures and Conversations on Aesthetics, Psychology and Religious Belief (Oxford: Blackwell, 1967)

${ }^{36}$ G. Hallett, A Companion to Wittgenstein's Philosophical Investigations (Cornell University Press, 1977)
} 
Freud. The executors of Wittgenstein's literary estate, all of whom had been his students, were particularly protective of the material in their hands, and this attitude extended to other former students including those who had transcribed Wittgenstein's lectures on art, psychology and religion. It is to Barrett's credit, therefore, that he was able to persuade them to allow him to edit this material for publication. No doubt his success owed much to his charm, confidence and considerable knowledge of the areas in question, additional to philosophy itself. Quite apart from his writings this was a real contribution to the study of philosophy be it of an under-labouring kind.

Finally, in relation to Wittgenstein and the interpretation of his thought, it is ironic that Elizabeth Anscombe should have found herself corrected by an Italian Jesuit in purportedly quoting in print from the Tractatus for the purpose of showing that Wittgenstein disavowed a verificationist account of meaning. Writing in 1954 about 'What Wittgenstein really said' she observed 'He says, "Every proposition makes sense," thus rejecting the whole idea of a criterion of meaningfulness which is commonly ascribed to him'. ${ }^{37}$ In reply Giancarlo C. Colombo S.J., who was then at Campion Hall preparing an Italian translation of the Tractatus, wrote 'I cannot find in the Tractatus the statement "Every proposition makes sense" which Miss Anscombe quotes (Prop. S. 4733 says something quite different)'. ${ }^{38}$ To this she responded frankly 'I must thank him for having caught me out: I invented the quotation ... In what follows I give references'.${ }^{39}$ Later in her Introduction to Wittgenstein's Tractatus she also credits Colombo with observing that the isomorphism between language

\footnotetext{
${ }^{37}$ G.E.M. Anscombe 'What Wittgenstein really said' Tablet 17 April, 1954.

${ }^{38}$ G.M. Colombo, 'The Tractatus of Wittgenstein' Tablet 15 May 1954, 18.

${ }^{39}$ Anscombe, 'The Tractatus of Wittgenstein' Tablet 15 May 1954, 18.
} 
and world is symmetrical raising the question of why only one side is said to be a description of the other. ${ }^{40}$

\section{VII}

Seeking other examples of Jesuit contributions one would naturally look first to a slightly earlier period than Suarez and to the commentaries on classics of Christian Aristotelianism such as the lectures on Aquinas's Summa Theologiae given in the Collegium Romanum by Francisco de Toledo ((1532-96), or those on the same text given at the Portuguese universities of Coimbra and Evora by Luis de Molina. The Jesuit contribution to the development of Thomism in the sixteenth century, be it of broad and often eclectic sort, owes much to the integration of the study of Aquinas's major writings, principally the Summa Theologiae in the syllabuses of Jesuit programmes of study, the most systematic and determinative of which with regard to Aquinas is that set out in the Disposition and Order of Studies written in 1552 by Jeronimo Nadal who had known Ignatius Loyola and the other original members of the Society when they were students at the University of Paris together but did not join then until around 1545 after which he became a central figure in the life of the Society.

Moving from late scholastic/early modern 'second thomism' to the nineteenth century neo-Thomist revival, Jesuits are again major figures in shaping and advancing the recovery and application of Aquinas. In Italy Serafino Sordi (1793-1865) taught at the Jesuit College at Modena and wrote Thomistic manuals that continued to be printed to the end of the second world war. Among his students was Giuseppi Pecci older brother of Vincenzo who would

\footnotetext{
${ }^{40}$ Anscombe, An Introduction to Wittgenstein's Tractatus reprinted in Mary Geach \& Luke Gormally eds. Logic, Truth and Meaning: Writings by G.E.M. Anscombe (Exeter:
} ImprintAcdemic. 2015) 53. 
later become Leo XIII. The brothers had previously been students together at the Collegium Romanum though only Giuseppi entered the Society of Jesus. As Pope, with advice and support of Giuseppi whom he elevated to the Cardinalate, Leo advanced the position of Thomism as the favoured philosophical handmaiden of Catholic theology. In 1879 he issued the encyclical Aeterni Patris, established the Pontifical Academy of Thomas Aquinas, and commissioned a critical edition of Thomas's writings. The main Jesuit contribution to Aeterni Patris itself, however, was the German Jesuit Joseph Kleutgen (1811-83) who wrote the first draft of the encyclical which led directly to the development of modern neo-Thomism and established the status of Aquinas as the philosopher of Catholicism. ${ }^{41}$

In the twentieth century, however, Jesuits began to reinterpret Aquinas's ideas within the framework of modern and recent philosophies. These latter made simple restatements, through teaching manuals, no longer adequate, acceptable or even intelligible. Those who did not set Aquinas aside sought to show that on suitable reinterpretation he could be squared with or come sufficiently close to what the world of philosophy in general regarded as important and permanent insights. These included the historically conditioned and developmental character of thought and human subjectivity proposed by Hegel and taken up in one form by Teilhard de Chardin; and the idea that experience of the world is mediated via forms of sensibility and broad categories of thought presupposed to particular conceptions, as argued for by Kant and developed a la Thomas by such prominent figures as Joseph Marechal and Bernard Lonergan - a sometime Heythrop student.

These remarks concern Jesuits in relation to Aquinas and later scholastic thought; but as the earlier discussion of Boscovich indicated, Aquinas was not always in favour and at times scholastic Aristotelian was set aside if not actually repudiated. The period of the late

${ }^{41}$ On Kleutgen and neo-Thomism see G. A. McCool, S.J. Nineteenth Century Scholasticism: The Search for a Unitary Method (New York: Fordham University Press, 1989). 
seventeenth and early eighteenth centuries does not get much discussion in the history of Catholic philosophical thought partly because of the actual decline in that period of the tradition of creative philosophical writing and teaching which represented a sense of retreat from if not defeat by new sets of ideas. As Copleston observes:

In the seventeenth, eighteenth and early part of the nineteenth centuries philosophy in ecclesiastical seminaries and teaching institutions generally tended to take the form of an uninspired Scholastic Aristotelianism amalgamated with ideas taken from other currents of thought, notable Cartesian and, later, the philosophy of [Christian] Wolff. And it lacked the intellectual vigour which was required to make its presence felt in the intellectual world at large. ${ }^{42}$

Even in historically Catholic Europe it was a difficult time for the Church of Rome and for religion more generally with the spirit of Enlightenment becoming increasingly secular and even anti-religious. It was also to be a difficult time for the Society of Jesus which was suppressed in Portugal in 1759 and in France in 1762 with the subsequent sale of the contents of the library of the premier Jesuit academy the College Louis-le-Grand. In 1767 came the expulsion from the Spanish Empire, and in 1773 they were suppressed in PolandLithuania, where John Hay, a Scottish Jesuit and graduate of St Andrews, himself aptly a Scotist rather than a Thomist, had established the School of Philosophy and served as the University’s first Librarian. ${ }^{43}$ That was also the year of their papal suppression by Clement XIV.

${ }^{42}$ Copleston A History of Philosophy, Volume 7: Modern Philosophy (London: Burns \& Oates, 1963) 387-8.

${ }^{43}$ See R. Darowski, 'John Hay S.J. and the Origins of Philosophy in Lithuania' Innes Review (1980) 31, 7-15. 
Notwithstanding secular intellectual, political and ecclesial pressures, however, through the late seventeenth and eighteenth centuries the Society of Jesus continued to produce important intellectuals who though (and perhaps because) they worked outside traditional scholasticism) contributed significantly to philosophy. We saw earlier Boscovich's course in the direction of scientific philosophy, but a lesser known figure whose field was more traditional, though again not Thomistic was Claude Buffier S.J. (1661-1737). Born in Poland of French parents, the family returned to Rouen where he was educated at the local Jesuit college before entering the Society in 1679, and after teaching in Paris and back in Rouen he returned to the capital to a position of 'scriptor' (writer) at the College Louis-leGrand which he occupied until his death. Buffier wrote on a wide variety of subjects but in this context, and perhaps quite generally, his most important work was Traite des Premieres Verities et de la source de nos judgements (1724) (On First Truths and on the Origins of our Judgements). This is a work of epistemology and metaphysics that engages in rather complex ways ideas of Descartes, Locke, and Berkeley. In response to skepticism it introduces the idea that particular judgements of perception and memory presuppose certain first principles of common sense that are not themselves open to serious doubt since they are conditions of the possibility of familiar sorts of judgements, and no proposition that could if true contradict them could ever be more credible than the principles themselves. This anticipates by two centuries ideas proposed by G.E. Moore and Wittgenstein, but more immediately it seemed close to what Thomas Reid advanced in his Inquiry into the Human Mind on the Principles of Common Sense published in 1764 forty years after Buffier's Traite 1764. This led to the English translation of Buffier's text carrying an anonymous preface accusing Reid and others of his school of plagiarism. Reid responded indirectly and the general consensus is that in his case at least the charge in unsubstantiated. ${ }^{44}$ The point remains, however, that in the modern

\footnotetext{
${ }^{44}$ See Louise Marcil-Lacoste, Claude Buffier and Thomas Reid: Two Common-Sense
} 
sense of the expression, 'the philosophy of common sense' proposed as a response to skepticism was first developed not, as is generally assumed, by the Scottish Presbyterian minister Thomas Reid but by the French Jesuit Claude Buffier.

\section{VIII}

Earlier I indicated a set of questions that might be posed in response to the third part of my title, and to these may be added queries about the meaning of the phrase 'contributions to philosophy' What is to count as a contribution and what is meant by philosophy? This question may not be as pedantic as it sounds. In reflecting on the examples I have given one needs to distinguish between different kinds of contributions, differentiating between those ad intra: ones that influenced or added to the practice of philosophy within Jesuit formation and teaching, and beyond that to the place of philosophy within the Catholic Church; and those ad extra: which made a difference to the study and practice of philosophy more broadly, or which could be invoked to do so. In that ad extra category are some of Suarez's metaphysical ideas, in particular concerning causation and the relation of properties to their natural bearers. Contemporary epistemology and metaphysics have difficulties giving account of our common, non-scientific knowledge of natural causation and accommodating the fact that causation itself resists any general analysis. To a scholastic this is hardly surprising since the notion of cause is analogical not univocal, but saying that does not go very far. What we find in Metaphysical Disputations 17-19 in the treatment of efficient causation is profound and has much to contribute to contemporary debates. Beyond that, however, is the very general and important question of the relationship between observed characteristics and the natures of things of which they are characteristics. Suarez writes:

Philosophers (Quebec: McGill-Queens University Press, 1982). 
The accidental properties, especially those that follow upon or are owed to a substance by reason of its form are caused by the substance not only as a material cause and a final cause but also as an efficient cause through a natural resultance ... It is probable that the substantial form has a certain power for having its proper accidents emanate from it. Likewise in this way one discerns more clearly the natural connection between a substantial form and its properties. $^{45}$

This reads like a stock item of scholastic terminology, but it points to the deep insight that the relation between proper characteristics (propria) and natures is not a contingent one but nor is it logical, rather the nature is the intelligible cause of the characteristics which explains how we can form conceptions of what things are on the basis of how they normally appear. As with Buffier's account of knowledge as presupposing natural cognitive dispositions this idea can be deployed in defence of philosophical realism: the idea that the world has an intelligible structure and that we are equipped to make sense of that structure. It also bears on the coherence of attempts in contemporary philosophy of mind to combine property dualism with substance physicalism.

A further distinction to be drawn in considering the character and significance of contributions to philosophy is that measured by breadth of influence which itself may not always be appreciated. To illustrate the latter, the nineteenth century Scottish philosopher James Frederick Ferrier conceived the need for a branch of philosophy focused on the forms and foundations of cognition, which he described as 'the theory of knowledge' and for which he coined the novel term 'epistemology'. The broad study of philosophy anywhere in the

${ }^{45}$ F. Suarez, On Efficient Causality: Metaphysical Disputations 17, 18 and 19 trans. F. Freddoso (New Haven: Yale University Press, 1994) 18, 3.4. 
western world today would be deemed incomplete without some introduction to the theory of knowledge or 'epistemology'; yet few philosophers have heard of Ferrier and few of those have read the work in which he introduced these ideas. His contribution is broad but largely unrecognized. Another example is one observed by Copleston who in discussing the influence of Christian Wolff's taxonomisation of the different branches of philosophy as subdivisions of the two forms: theoretical and practical observes the indebtedness of this to scholasticism, and in particular the prior use of the tern 'ontology' to describe the field of general metaphysics by John Baptiste Duhamel in his Philosophia vetus et nova ad usum scholae accommodata $(1678) .{ }^{46}$

With these examples in mind let me return to the case of recent Jesuits and consider Bernard Lonergan, contrasting him with the most famous academic ever to have been on the faculty of Heythrop. Copleston's nine volume History of Western Philosophy was a first and in many cases last work of reference for two or three generations of philosophers and philosophy students across the English-speaking world. It was viewed as reliable both because the author evidently knew a great deal about his subjects and because his method was one of impartial presentation, not favouring or disfavouring figures or ideas because he was either keen or hostile towards them. Readers of Copleston were not only absorbing information about philosophers and their ideas but acquiring a conception of how the history of philosophy should be done. It may have seemed common sense, but to those outside the anglophone world who lived under the influence of ideological education the situation was very different; and within the English-speaking world a new approach was gaining ground, associated with quasi-Hegelian figures such as Alasdair MacIntyre and Charles Taylor who saw history of philosophy as partly cultural critique.

${ }^{46}$ F. C. Copleston A History of Philosophy, Volume 3: Ockham to Suarez (London: Burns \& Oates, 1963) 356. 
The contrast I wish to draw, however, is not that between Copleston and these later figures but between him and Lonergan. The first had influence of the kind described not through any 'original contribution' in the obvious sense; while the latter produced a monumental work that attracted disciples and has led to the establishment of dedicated societies, programs and publications. Yet Lonergan's ad extra influence within professional academic philosophy has been negligible. Anyone who doubts this must consider the fact that the online Stanford Encyclopedia of Philosophy, which is now the most widely consulted English-language general work of reference for the subject, not only has no article on Lonergan, but does not mention him anywhere among the 1,500 entries, while Copleston is cited in the references to entries on Aquinas, Descartes, Leibniz, Russell, Schopenhauer, the cosmological argument, and medieval philosophy.

While this neglect should be remedied, it calls for some explanation. One may say that this is a provincial measure but the province in question is pretty vast. Lonergan's essays on St Thomas's account of cognition assembled under the title Verbum: Word and Idea in Aquinas represent a return to the Jesuit Thomistic commentary tradition, and his essays on education are similarly in an identifiable Jesuit tradition dating back to Ignatius and Jerome Nadal. But it is quite another thing to venture out on one's own as a creative philosopher, something which Copleston rarely sought to do. Lonergan may have been influenced by the example of De Chardin, at any rate to the eye of an analytic philosopher both authors tend to the repeated application of a formula. Both attract devotees with many associations, publications and activities dedicated to them; but this is often a sign that people are treating an author as a sage or guru rather than as a critical thinker.

Copleston, by contrast, is under-rated in being viewed as a mere chronicler of philosophy for he was in fact a thoughtful contributor to metaphilosophy and to the philosophy of the history of philosophy, a point which is related to what I shall claim is the 
perennial Jesuit contribution: the adaptation of philosophical thought to the circumstances and the needs of human life. ${ }^{47}$ In the four years between Heythrop being admitted to the London faculty of Theology in 1971 and that of Arts in 1974 Copleston served as Principal and was awarded by the University the title 'Professor of the History of Philosophy'. Retirement from this position came in 1974 when he also demitted the headship of the College. This short period meant that his Professorial inaugural lecture in 1973 was in effect also a valedictory, and it bears the mark of recollection and reflection.

That was apt, however, given its theme: 'The History of Philosophy: Relativism and Recurrence'. ${ }^{48}$ In it Copleston observes that when he embarked on the first volume of his History of Philosophy he stated that he was approaching the subject from the perspective of 'a scholastic philosopher' and that he then believed that Thomism (be it in 'a wide sense') is a 'perennial philosophy', but over the course of the series he had come to think about the historical development and changing cultural role of philosophy in ways that moved him from his original position. I spoke of the Jesuit habit of engaging and often adopting the ideas of a given period, and said that this has been viewed as accommodationism and criticized as a

${ }^{47}$ Copleston also had a longstanding interest in the philosophy of language, specifically the criteria of meaningfulness, likely motivated by concern about challenges to the meaninfulness of religious language. He wrote on these issues over many years from a problematic rather than a historical perspective. See Copleston, Contemporary Philosophy: Studies in Logical Positivism and Existentialism (London: Burns \& Oates, 1956) and other items listed in 'Frederick C. Copleston: An $80^{\text {th }}$ Birthday Bibliography' Heythrop Journal 28 (1987) 418-38.

${ }^{48}$ F. C. Copleston, 'The History of Philosophy: Relativism and Recurrence'. The Heythrop Journal, (1973) 123-35, reprinted in Copleston, Philosophers and Philosophies (London: Search Press, 1976). 
form of relativism. The analogous charge against Copleston's revised view would be that of historicism; but I think this misidentifies his position, just as the accusation of accommodationism often mischaracterizes practices of engagement and adoption. These are large and contentious issues but the point is that in his reflections on the history of philosophy in general, Copleston ascended from the position of being an accomplished historian of philosophical ideas to being a practitioner of the philosophy of the history of philosophy, and what he has to say as a historically-oriented metaphilosopher in his inaugural lecture and in subsequent books is well worth considering and taking account of in assessing his contribution to philosophy ad extra. ${ }^{49}$

\section{IX}

In The First Jesuits and in other writings, e.g. on the development of the Ratio Studiorum, John W. O' Malley, S.J. points out that the early Jesuits were subject through their education to both scholastic and humanist influences, and these somewhat different approaches to the life of the mind and to the application of thought in action entered into the nature of the Society. ${ }^{50} \mathrm{He}$ traces that through different fields, principally those of ministry, worship, prayer, education and culture. I think this is also a prominent feature of Jesuit contributions to philosophy. In his little book on Aquinas, GK Chesterton writes

Since the modern world began in the sixteenth century, nobody's system of philosophy has really corresponded to everybody's sense of reality; to what, if

${ }^{49}$ See in particular Philosophers and Philosophies, op. cit., On the History of Philosophy and Other Essays (London: Search Press, 1979), Philosophies and Cultures (Oxford: Oxford University Press, 1980), and Religion and the One (Tunbridge Wells: Search Press, 1982). ${ }^{50}$ J. W. O'Malley, The First Jesuits (Cambridge, MA.: Harvard University Press, 1993). 
left to themselves, common men would call common sense ... Needless to say, I am not so silly as to suggest that all the writings of St. Thomas are simple and straightforward; in the sense of being easy to understand. ... The only point I am stressing here is that Aquinas is almost always on the side of simplicity, and supports the ordinary man's acceptance of ordinary truism. ${ }^{51}$

To the extent that I have a thesis about what constitutes the unifying character of Jesuit contributions to philosophy it is that, whether or not they are specifically Thomistic, and if so whether narrowly or broadly such, they are in the spirit of Aquinas as Chesterton characterises it. On one level this is to say that they are broadly realist, asserting the existence and intrinsic intelligibility of the real, and affirming the human capacity to know it. The efforts of Suarez and Buffier are but two important examples of that realism. But on the other hand Jesuit contributions are generally marked by a humanistic disposition, by which I mean a concern to articulate an ennobling conception of human nature as rational in cognition, in affection and in action. This feature also serves to account, I believe, for the trend in Jesuit ethical writing to move from the general abstract ideal to the specific and sometimes exceptional, particular concrete real - a move encouraged and seemingly warranted by the early attachment to Aquinas who in the Summa Theologiae contrasts arguments in speculative and practical reason:

As to the proper conclusions of the speculative reason, the truth is the same for all, but is not equally known to all: thus it is true for all that the three angles of a triangle are together equal to two right angles, although it is not known to all. But as to the proper conclusions of the practical reason,

${ }^{51}$ G.K. Chesterton, St Thomas Aquinas (London: Hodder \& Stoughton, 1933) 173. 
neither is the truth or rectitude the same for all, nor, where it is the same, is it equally known by all. Thus it is right and true for all to act according to reason: and from this principle it follows as a proper conclusion, that goods entrusted to another should be restored to their owner. Now this is true for the majority of cases: but it may happen in a particular case that it would be injurious, and therefore unreasonable, to restore goods held in trust; for instance, if they are claimed for the purpose of fighting against one's country. And this principle will be found to fail the more, according as we descend further into detail, e.g. if one were to say that goods held in trust should be restored with such and such a guarantee, or in such and such a way; because the greater the number of conditions added, the greater the number of ways in which the principle may fail, so that it be not right to restore or not to restore. Consequently we must say that the natural law, as to general principles, is the same for all, both as to rectitude and as to knowledge. But as to certain matters of detail, which are conclusions, as it were, of those general principles, it is the same for all in the majority of cases, both as to rectitude and as to knowledge; and yet in some few cases it may fail, both as to rectitude, by reason of certain obstacles. ${ }^{52}$

I indicated how Molina affirmed human freedom and the capacity for cooperation with grace against the Calvinist interpretation of Paul and Augustine which viewed the operation of grace as overpowering human agency - an agency in any case corrupted in its motives and

\footnotetext{
52 Thomas Aquinas, Summa Theologiae, Literally translated by Fathers of the English Dominican Province (London: Burns, Oates and Washbourne, 1920) Ia IIae, q. 94, a. 4, response.
} 
exercise by $\sin$ (a non-theological equivalent might be formulated in terms of moral luck and individual control). Similarly in the Jansenist debates the Jesuit disposition was to uphold the capacity, and affirm the responsibility, to engage in practical deliberation with all of its difficulties of identification and interpretation of the factors bearing on right choice. In that context I referred to circumstance, character, and intention, added to which Jesuits in more recent times have tended to emphasise conscience. ${ }^{53}$ Claudio Acquaviva, the fifth Superior General who promulgated the Ratio Studiorum, and who permitted Parsons to use the bequest of Doña Luisa to purchase the house in Louvain for the establishment of the College of which Heythrop is the existing embodiment, wrote a manual for Jesuit spiritual directors entitled Industriae ad curandos animae morbos (1600) - 'Treating illnesses of the soul'. In it distinguishes in various ways between adherence to principle or general truth, and care and prudence in the manner of dealing with particular cases. On this account he is widely credited with coining the maxim 'fortiter in re, suaviter in modo' usually rendered as 'firmly in action, gently in manner'. While this may be an instance of what he has in mind the Latin expression does not, so far as I can discern, appear in the original text. It suggests, however, a

${ }^{53}$ Here it is appropriate to note the work of Gerard J. Hughes S.J. who taught in the Department of Philosophy at Heythrop for almost 30 years, before taking up the Mastership of Campion Hall, Oxford. Of particular relevance are Authority in Morals: An Essay in Christian Ethics first published in 1978 in Heythrop Monographs and thereafter by Sheed \& Ward, and by Georgetown University Press; The Nature of God: An Introduction to the Philosophy of Religion (London: Routledge, 2005); and Guidebook to Aristotle's Nicomachean Ethics $2^{\text {nd }}$ edition (London: Routledge, 2013). The flourishing of philosophy at Heythrop and respect for it elsewhere in the University was largely to do with his work including the chairing of the department there. 
broader outlook in which abstractions are acknowledged as idealisations while human reality is taken to be the context in which thought and action have to be worked out.

Conceiving matters in this way and recognizing that Acquaviva was both interpreting the mind of Ignatius Loyola and directing the minds of his confreres one may appreciate that the Jesuit tradition is heir to an ancient conception of philosophy, now generally dismissed as not part of the subject conceived of as an intellectual discipline or science: namely the practice of the love of wisdom. In plainer terms, one may see in the work of Jesuit philosophers the idea that however far speculation may range, if it is to contribute to the human good then it must return to inform the understanding of the human in relation to reality more generally, and engage with fundamental questions about practice and meaning. In this regard philosophy as studied and taught in the Jesuit tradition is not an altogether autonomous exercise since it contributes to a spiritual purpose, one characterised by Ignatius of Loyola when he wrote in his first annotation of the text of The Spiritual Exercises:

By the term 'Spiritual Exercises' we mean every method of examination of conscience, meditation, contemplation, vocal or mental prayer, and other spiritual activities, such as will be mentioned later. For, just as taking a walk, traveling on foot, and running are physical exercises, so is the name of spiritual exercises given to any means of preparing and disposing our soul to rid itself of all its disordered affections and then, after their removal, of seeking and finding God's will in the ordering of our life for the salvation of our soul..$^{54}$

\footnotetext{
${ }^{54}$ Ignatius Loyola, The Spiritual Exercises trans. C. Seager (London: Dolman, 1847) 1.
} 
This is not to say that philosophy is just a form of spirituality, but unless it conduces in some way to a spiritual end, whether the particular one specified by Ignatius, or the broader one suggested by Copleston when he writes of that 'metaphysics can be looked on as man's appropriation in reflection of his own orientation to the transcendent Absolute' then it is hard to see why a Jesuit qua-Jesuit should be especially interested in it, or judge it necessary for his own education and desirable for the education of others to study, and where means and opportunity exist to contribute to the practice of philosophy. It is not accidental that Ignatius and his confreres in the University of Paris all studied philosophy, or that the academic study of the subject has been a central part of Jesuit formation and of the education provide by Jesuits to others. This then gives one way of interpreting such claims as that 'Heythrop is not an institution that can be replaced by anything equal or equivalent to it'. Since entering London University it has become more secularized and laicized, but through those decades as throughout its longer history the leadership of the College has remained the responsibility of Jesuits formed in the Ignatian tradition in which the orientation towards transcendence has been seen, as Copleston implies, not as contrary to the reality of the human condition but as an expression of it.

JOHN HALDANE (ijh1@st-andrews.ac.uk) is Professor of Moral Philosophy at the University of St Andrews and J. Newton Rayzor Jr. Distinguished Professor of Philosophy at Baylor University, Texas. His many publications include Faithful Reason and Reasonable Faith (both Routledge). 